\title{
Then, There Were Nine: The Forgotten Higher Schools of
}

\section{Imperial Japan}

\author{
Kaoru Yamamoto ${ }^{1 *}$ \\ ${ }^{1}$ Educational Psychology, University of Colorado, Denver, Colorado, USA \\ *Kaoru Yamamoto, E-mail: kaoru7.yamamoto@gmail.com
}

\begin{abstract}
Following the Meiji Restoration of 1868, Japan hurried to modernize all aspects of the new nation-state and prevent colonization by Western powers. As a critical element in that effort, a centralized system of education was created, compulsory schooling instituted, and advanced schools were established. A further development saw, in a single Taisho decade of the 1920s, the birth of nine higher schools of an articulated structure with progressive pedagogical perspective. In the following Showa era, Japan's defeat in the Second World War resulted in a wide-ranging reshuffling of its education system, first imposed by the victorious Allied Occupation Forces. In that process, with little appreciation of the significance of their venture, all of the unique institutions were summarily abolished in 1950. This article traces the history of the obliterated schools and closely examines the virtues of their educational approach in the light of modern studies from the East and West.
\end{abstract}

\section{Keywords}

on the horizon of the present, the wisdom in the erased past, the articulation of school structure for the developmental continuity

\section{Introduction}

A proper understanding of historical events requires a broad perspective and continuous testing of all our prejudices. An important part of this testing is the open encounter with the past and the understanding of the tradition from which we come. "Hence the horizon of the present cannot be formed without the past" (Gadamer, 1986, p. 273).

Sometimes, worthy efforts for reform and betterment are totally eclipsed by later events of cataclysmic nature. Such was the case of a small number of Japanese higher schools, born in a pre-WWII decade, only to suffer a premature death in the post-defeat tumult during the broad "revolution from above" (Dower, 1999, p. 69). In the wake of the turmoil, the history of these institutions received little or no attention in the later reform efforts.

This article reviews their short life in the troubled times of the nation, and examines what can, and should, be learned from the bygone efforts for the improvement of future education. 


\section{The Dawn of a New Nation}

The seldom-acknowledged legacy of the feudal period of Japan [1603-1867] included the relative stabilization of the whole society, the development of the social infrastructure, and the improvement of many aspects of daily life (Hanley, 1997), encompassing the formal schooling. By the time the long reign of Tokugawa shogunate was approaching its end, "many of the educational developments in the period following the Meiji Restoration [of 1868] had been underway for some time, considerably easing the adjustment to a modern system" (Rubinger, 1989, p. 224). In fact, in the mid-19 $9^{\text {th }}$ century, the institutions for schooling had increased to an impressive number like 17,000. "Although not recognized as such at the time, Japan in 1868 had a better educated populace than many Western countries" (Bowring \& Kornicki, 1993, p. 245).

The government under Emperor Meiji was keenly aware of the external threat of colonization and, accordingly, of the urgent need for the unification of people. The goal was as rapid a transition as possible to an independent, modernized nation-state. "Japan had to 'achieve its place', and it could best do so if its citizens achieved theirs" (Jansen, 2000, p. 460). Thus, "it is significant that the Meiji rulers decided to concentrate on developing education for the general population and not just the élite... [T] here was general agreement that education, even for the lower classes, was highly desirable" (Bowring \& Kornicki, 1993, p. 245).

\subsection{Development of a Centralized System of Education}

Following the proclamation of the Fundamental Code of Education in 1872 (MEXT (Note 1), 1980, section II-2), a three-tiered approach was adopted to enable the citizens to achieve their place. To begin with, school districts were established throughout the country, each providing a stipulated number of institutions at different levels.

The first tier consisted of primary schools of eight years' duration (four lower, four upper). The next tier was that of secondary schools of total six years (three lower, three upper). The third was a national university to raise the new leaders of competence, not of rank.

In addition, a separate track of post-primary vocational schools was planned in agriculture, engineering, commerce, foreign language, and teaching (the so-called normal schools).

The overall Code was to see several revisions during the Meiji era of 1868-1912 (MEXT, 1980, II-2). The changes in 1880 reduced the primary schooling from eight years to six. Then, the 1890 Primary School Order made compulsory the first four of the six years, and also stipulated that the secondary schools were to consist of lower five years (for both boys and girls) and upper three years (mostly for boys). An exception was the pioneering Tokyo Girls' School opened in Tokyo in 1875, much later to become Ochanomizu University in 1949. Meanwhile, in the late 1890s, private "mission schools" of various Christian denominations served to strengthen the mid-level education for girls (ibid., I-1-3-3, II-3-3-e, II-5-4-b, III-4-2). Additionally, in 1899, each prefecture was required to establish at least one upper secondary school for girls. 
By the turn of the century, the centralized recasting of the old schooling system had been mostly accomplished for the new age, and the revision of 1908 made all six primary years compulsory. The official statistics for the year 1909 gave the attendance rate of school-age children for the compulsory education at 98.86 percent for boys and 97.26 for girls, making it 98.1 percent overall (ibid., Appendix: Statistics I-4).

\subsubsection{Higher Education}

In spite of the stipulations in the 1872 Code, the very first public institution of higher education did not arrive until 1877. In October of that year, again confirming the value of the Shogunate groundwork, the Imperial University of Tokyo was established by merging the three Edo-era schools: Shōheikō (teaching Japanese and Chinese literature from 1789), Yōgakusho (Occidental studies since 1855), and Shutōsho (medical studies from 1860). The new Faculties of Law, Science, Literature, and Medicine, plus Graduate School, were to see the addition a decade later of Engineering and Agriculture (ibid., III-5-1). The institution quickly established itself as the Oxbridge of Japan. Meanwhile, the advanced education of many a future leader during the Tokugawa-Meiji transition period continued to be carried out by, in addition to the central, national university, a number of pioneering private institutions, typically initiated by a remarkable leader. That cluster, later officially recognized as legitimate universities, included Keiō Gijuku (Tokyo, 1858, by Yukichi Fukuzawa), Ritsumeikan (Kyoto, 1869, by Kinmochi Saionji), Rikkyō Gakkō (Tokyo, 1874, by Episcopalian Bishop Channning Williams), Dōshisha Academy (Kyoto, 1875, by Jō Nījima), Waseda Gakkō (Tokyo, 1882, by Shigenobu Ōkuma). On the female side, they were soon followed by Tokyo Women's Medical School (1900, by Ms. Yayoi Yoshikawa), Women's Eigaku Juku (the later Tsuda Juku; 1900, by Ms. Umeko Tsuda), and Nihon Women's College (1901, by Jinzō Naruse) — all three located in Tokyo. As the feeder schools matured in the subsequent decades, the higher education system was further expanded. First, a second Imperial University was built in Kyoto in 1897 and, thereafter, five others were to join the two under the direct jurisdiction of the Ministry of Education: Tohoku (in Sendai, 1907), Kyushu (Fukuoka, 1910), Hokkaido (Sapporo, 1918), Osaka (1931) and Nagoya (1939) (MEXT, 1980, IV-4-1). Of these, Tohoku was to become the pioneer in opening the door to women in 1913 (Yoshino \& Kusano, 1999).

\subsubsection{Secondary Education}

Under the 1872 Code, the secondary schools were to consist of the total duration of six years: three years in the lower section and three in the upper one. But, the 1886 revision of the Secondary School Order made the lower part, now called the ordinary secondary school of five years, part company with the upper secondary school of three years. The Ministerial intent for the latter was to "carry out the education necessary for those who wish to go into business as well as those who wish to enter a higher level school" (MEXT, 1980, III-5-2-a). For that purpose, the former preparatory school for the Imperial University of Tokyo was transformed into the First Higher Secondary School (in Tokyo, 1886), followed by the Second (Sendai, 1887), Third (Kyoto, 1886), Fourth (Kanazawa, 1887), Fifth (Kumamoto, 1887), Sixth (Okayama, 1900), Seventh (Kagoshima, 1901), and Eighth (Nagoya, 1908). 
In spite of the original dual aims of the Government, however, all these schools essentially became preparatory institutions for the Imperial Universities without developing more practical programs for various disciplines. Accordingly, by the 1894 Higher School Order, all the higher secondary schools became explicit organs of higher education, thenceforth to be known as the higher schools with a three-year curriculum. Further, by the 1918 Higher School Order (by then, under the reign of Emperor Taisho [1912-1926]), select prefectural and private institutions were recognized at both university and higher school levels, side by side with those under the direct jurisdiction of the Ministry of Education itself. As a result, in the ensuing years, a total of 18 national, two prefectural, and four private higher schools were newly built in cities all over Japan (MEXT, 1980, IV-4-2). Even though the 1918 Higher School Order stipulated that these schools were to be "organized on a seven-year system of which three years were devoted to higher courses and four to ordinary courses", it also allowed that, "in special cases schools could be established with only the three-year higher course" (ibid.). It so happened that, of the total 34 higher schools, extant in pre-WWII Japan, 25 (all but one having been built between 1886 and 1923) opted for the special case provision to offer only the three-year, higher course. Under said Order, the maximum number of students in these schools was fixed at 600 , while the maximum class size was limited to 40 . The typical applicant would have graduated from a primary school of six years, plus a lower-secondary school of five years, to face a screening examination to enter a higher school of choice. The admission rates then ranged from 10 to 15 percent (Hata, 2003, p. 93).

\subsubsection{The World of the Original Higher Schools}

The young men of these schools were readily identifiable by what they wore-a round, black hat, trimmed with white ribbons, with a visor and a school insignia up front; a black uniform; a heavy black mantle; and high wooden clogs. They took special, adolescent pleasure in the shabbiness of attire and the unkemptness of appearance!

Mostly living in self-governing dormitories on closed campuses, they in turns engaged themselves in serious intellectual pursuits, deep self-reflections and lively debates, and boisterous merrymaking and fooleries. In Japan of the day, their ready models were the shishi of Meiji, namely, those young patriot-warriors who laid down their lives for the Imperial restoration and unification of the nation. A deeply felt sense of being "the chosen ones"-fully expected to lead the whole nation for enlightenment and progress - found various manners of expression, sometimes extreme and often self-contradictory. Indeed, "secluded as a united family of men, these higher schools scorned the world beyond their gates as vulgar and feminine, despising even the physical presence of women... [They] displayed great concern for manliness and the rituals of privileged masculinity" (Rose, 1992, p. 130). On the other hand, their idealism, if somewhat naïve, was palpable, and their thirst for knowledge, autonomy, and competence was deep. "He is the shosei (student) to whom the earth is too small and the heavens are not high enough. He has his own theories of the universe and of life. He dwells in castles of air and feeds on ethereal words of wisdom. In his eyes beams the fire of ambition; his mind is athirst for knowledge... He is the repository of loyalty and patriotism. He is the self-imposed guardian of 
national honour. With all his virtues and his faults, he is the last fragment of Bushidō [the way of samurai warriors]" (Nitobe, 1908, Chapter 16).

Statistics show that an overwhelming majority of the successful entrants to the seven national universities came from these, quite selective higher schools. For instance, the 1940 figures revealed that 96 percent of those accepted by the Imperial University of Tokyo originated in them. The comparable figures were 92 percent for Kyoto, 81 for Nagoya, 79 for Tohoku, and 75 for Osaka (Hata, 2003 , p. 45). When juxtaposed with such other records as " 73.6 percent of the higher civil servants and 49.7 percent of judicial officials [of the whole country in 1937] were graduates of the Imperial University" (Jansen, 2000, p. 408), it is difficult to dispute that the national universities and purpose-built higher schools, together, were fulfilling their mission, entrusted to them by the Meiji pioneers, to raise the next generations of leaders fast and well.

\section{Into the Maelstrom}

Thus, Japan had been rapidly transforming itself into a centralized country capable of competing with other "modernized" nations, and proving its own military-industrial prowess in the decisive victories over its two giant neighbors, China (1895) and Russia (1905). However, when Emperor Meiji died in the summer of 1912 after 45 years of reign, many "felt as though the spirit of the Meiji era ... begun with the Emperor ... had ended with him" (Natsume, 1957, p. 245). Indeed, some changes were in the wind. Jansen (2000, pp. 548-549) summarizes one aspect of the palpable shift as follows:

"In Meiji times young men occupied themselves with success, for themselves and for their new country... [However, once] the nation-state had been built [and] Japan had taken its place among the powers... the sense of collective national crisis was replaced by a sense of individual and existential crisis... Now what began to matter was... being rather than doing, and feeling rather than achieving... [T] he prevalence of concern with identity and purpose indicates that the Meiji cult of effort and success was losing its attraction for young men".

The short reign of the succeeding Emperor Taisho [1912-1925] was marked with both external and internal upheavals. The First World War [1914-1918] initially brought some economic benefits but then led Japan into financial setbacks and social unrests (Shiota, 1966). The Russian Revolution [1917-1920] abetted socialistic, anarchistic, and communistic ideas and labor movements. The big market crash of 1920 was followed by a series of recessions and banking crises (Ohno, 2006). Then, on September 1, 1923, the Great Kanto Earthquake of 7.9 magnitude hit and, with the ensuing tsunami and conflagration, devastated the whole Tokyo region plus six adjacent prefectures. About 143,000 people died, 502,000 were injured, and 3.25 million were left homeless (Kōdansha, 1993, pp. 1595-1596).

\subsection{Glimpses of Light}

Even during these tumultuous years, "there was a promising development known as "Taisho democracy", which took the form of "the emergence of greater political pluralism" (Dower, 1999, p. 180). The weight gained by the elected House of Representatives and the party governments resulted in 
the reduction of the power of earlier, non-elected organs (like the Meiji oligarchs) and their ability to interfere in the work of the cabinets.

Another important aspect... was increased popular involvement in politics, primarily through expansion of male suffrage and more widespread freedom of political expression. Emphasis on the broader ideals of social democracy included the recognition of labor and tenant-farmer unions and of greater equality for women (Kōdansha, 1993, p. 1501).

It was during this particular period of many a change that nine, new higher schools of unique features made their appearance. While 24 of the 25 older institutions had been built in the mid-Meiji to early-Taisho period (i.e., 1886-1923), the new creations all arrived on the scene within a single decade of 1921-1929 (see Table 1).

Table 1. Nine 7-Year Higher Schools of Japan

\begin{tabular}{llllll}
\hline & & & \multicolumn{3}{c}{ Year } \\
\cline { 4 - 5 } Name & Location & Jurisdiction & Opened & Closed & Total N of Graduates \\
\hline Tokyo & Tokyo & National & 1921 & 1950 & 3667 \\
Taihoku & Taipei & National $^{2}$ & 1922 & 1952 & 2472 \\
Toyama & Toyama & Prefectural & 1923 & 1950 & 3,329 \\
Naniwa & Osaka & Prefectural & 1926 & 1950 & 3,268 \\
Furitsu & Tokyo & Prefectural & 1929 & 1950 & 2840 \\
Musashi & Tokyo & Private & 1921 & 1950 & 1998 \\
Kōnan & Kobe & Private & 1923 & 1950 & 1648 \\
Seikei & Tokyo & Private & 1925 & 1950 & 1988 \\
Seijō & Tokyo & Private & 1926 & 1950 & 2890 \\
\hline
\end{tabular}

Note: ${ }^{1}$ Compiled by Kazuyo Satake (see Hata, 2003, pp. 38-40).

${ }^{2}$ Under the Japanese Government General of Taiwan.

The differences from the well-established, 3-year schools were clear from the very outset. To begin with, all nine were established in strict conformance to the 1918 Higher School Order. That is to say, all of them were of "a seven-year system of which three years were devoted to higher courses and four to ordinary courses" (MEXT, 1980, IV-4-2). The older higher schools admitted students into its 3-year "higher courses" by an entrance examination of applicants from among the graduates of the 5-year lower-secondary schools. In contrast, the 7-year arrangement screened students into the 4-year "ordinary courses" at the end of the primary school and then let them proceed into the 3-year "higher courses" without any intervening examination. While each grade in the ordinary courses had two classes of 40 students each, the maximum for the higher courses was 480 per the 1918 Order (i.e., 20 percent fewer than in the older schools). The difference in student sizes between the ordinary and 
higher courses was filled by means of an entrance examination of applicants from the older, 5-year lower-secondary schools.

Moreover, unlike the 3-year schools, which were all under the national or prefectural jurisdictions, the new arrivals were diverse in their lineage. In fact, the very first 7-year system institution, Tokyo Higher School, was the only one (within the archipelago itself) directly administered by the central government. Three others were prefectural, and four were private. In fact, some of the unique characters of these newer higher schools were reflected particularly clearly in the history of the four private institutions. First of all, under the 1918 Order, any would-be founder of a private higher school was required to secure a minimum endowment of $¥ 500,000$, or the equivalent of a little more than a quarter million dollars then. That amount is about 4 million dollars in 2011 (Officer \& Williamson, 2012). Remarkably, in all instances, some forward-looking business and education leaders, plus interested parents, managed to meet the formidable financial challenge. Of the four, however, only Musashi (Note 2) was tailor-made anew for the 7-year arrangement (Musashi, 1941), while the other three were created as an upward extension in the restructuring of already extant institutions (Kōnan, 1969; Seijō, 1998; Seikei, 1973).

\subsection{The Tempests}

Alas, the promising birth of these 7-year higher schools was to coincide with numerous, tumultuous developments on the national and international scenes. On the Christmas Eve of 1926, Emperor Taisho passed away, and the reign of Emperor Showa, 25-years-young, began in the aftermath of already noted disasters, plus many other stormy events-to-come, which proved as trying as those suffered by his father. The population explosion was one serious issue with already 50 million souls by 1910, the growth rate reaching 16.2 percent for the decade of 1920 (Japan Statistics Bureau, 2013, Table 2.2; Sasaki, 2008, Table 1). The partial solution to this predicament, namely, the emigration and contract labor across the Pacific, was effectively shut off by the U.S. Johnson-Reed Immigration Act of 1924 (Daniels, 1977). The economic woes of the 1927 banking crisis preceded the October 1929 Wall Street crash, leading the nation into the Showa Depression of 1930-32 (Ohno, 2006).

Meanwhile, the clashes with China, started in Manchuria in 1927, flared up into a full-scale invasion of Chinese mainland in July 1937. Numerous attempts at coup-d'état and assassinations of political, business, and rival military leaders took place in the homeland between 1927 and 1936. During this unsettling period, the ultranationalists targeted a dozen noted university and higher school professors for the expression of their liberal views.

The police also pursued students in these institutions, who showed interest in the study of the nascent socialism/Marxism (e.g., Furitsu A.A. (Note 3), 2005, pp. 51-74; Tōkō A.A., 2001, pp. 271-284; Toyama Daigaku, 2002, pp. 181-182).

In September 1940, Japan made a fateful pact with Germany and Italy to form the "Axis" power block, while the Japanese army established its presence throughout southeast Asia (Reynolds, 1994), thus threatening the whole European colonies so as to incur severe economic sanctions by the Western 
powers (Divine, 1965). Then, in early December of 1941, the Japanese attack on Pearl Harbor, Hawaii, signaled the spread of the Second World War into the Pacific. The consequences were to be calamitous for Japan (Bowring \& Kornicki, 1993, pp. 99-105).

As the fortune of war had steadily turned against the country, the government initially mobilized students for farm labor and factory work but, after 1943, conscripted students in secondary schools and universities. Alas, many never returned home-for example, 136 from Tōkō, or 7.5 percent of its total 1932-1942 graduates (Tōkō, 2001, p. 66, p. 125, p. 285), and 100 from Seikei (1973, pp. 487-493). The main building of the former was totally destroyed by the colossal fire bombings, while several facilities were damaged at Musashi and Seikei.

\subsection{Under the Yoke}

Once the instrument of surrender was signed by Japan on September 2, 1945, and the seven-year occupation by the American-led armed forces began, the country came under the tight grip of the SCAP (Supreme Command for the Allied Powers) of General Douglas MacArthur of the U.S. Army. Even though the military governance was ostensibly indirect in nature via the extant Japanese government, the SCAP insisted to get what it wanted right away in all realms of imposed changes.

"In numerous... ways, the contradictions of the democratic revolution from above were clear for all to see: while the victor preached democracy, they ruled by fiat... Their reformist agenda rested on the assumption that, virtually without exception, Western culture and its values were superior to those of "the Orient". At the same time, almost every interaction between victor and vanquished was infused with intimations of white supremacism... [T]he occupation was in this sense but a new manifestation of the old racial paternalism that historically accompanied the global expansion of the Western powers" (Dower, 1999, p. 211). Similar assessments were recorded by Harootunian (1993, pp. 196-221) and T. Yamamoto (1999).

\subsubsection{The "American Reform of Japanese Education"}

On the matter of formal schooling, the SCAP requested some assistance from back home in October 1945 and, early in 1946, the U.S. State Department assembled a group of 27 civilians and sent them as the United States Education Mission to Japan. The group was "a unique mixture of educators, religious leaders, and other fairly distinguished Americans", of whom "few, if any... had direct experience of Japan" (Duke, 1989, p. 261).

The Mission "spent one week in briefings after they arrived in Japan (on March 5, 1946), one week listening to SCAP and Japanese educators, less than one week observing, and one week compiling their Report" (Gluck, 1993, p. xii; Tsuchimochi, 1993, p. 3). The final document was submitted to the SCAP on, unbelievably, March 30, 1946. Given the particular historical circumstances, this lightening-quick report of the U.S. Education Mission had a decisive impact upon the course of educational reconstruction of the vanquished nation. It summarized "the ideals of American democratic education" and set "the pattern for the great American democratic reforms of Japanese education" (Duke, 1989, p. 261). The key changes included (a) the local control of education, (b) an upgrading of teacher education, 
(c) the revision of the curricular materials and instructional methods, (d) the inception of the coeducational schooling, (e) the adoption of a single track system of 6-year primary, 3-year lower secondary, and 3-year upper secondary schools to replace the prewar, multi-track arrangements, and (f) the compulsory and tuition-free schooling for the first nine years (MEXT, 1980, VI-2-3). The last stipulation added three extra years to the obligatory school attendance that had been in force in Japan since 1908 .

The stipulated transformations were swiftly carried out. "The new Constitution of Japan was... put in force on May 3, 1947", and its "Article 26 stipulated that... 'All people shall have the right to receive an equal education correspondent to their ability, as provided by law ..." Even prior to that, on March 31, 1947, the Fundamental Law of Education was put in force and the School Education Law was promulgated on the same day (MEXT, 1980, VI-2-6). Lower-secondary schools were officially initiated in April 1947, and the upper-secondary schools followed a year later (ibid., VI-3-1,VI-3-5). Then, in 1949, the new, 4-year university system made its debut. While the idea, initially preferred by the SCAP, of "one national university in every prefecture" could not be realized for several practical reasons, that difficulty ironically "paved the way to the development of junior colleges" (ibid., VI-3-6). Meanwhile, under the tumultuous circumstances, all 34 higher schools - the 25 older institutions of the 3 -year course as well as the 9 newer ones of the 7-year track-were summarily abolished as of March 1950. During their life spans of up to six and half decades, the older schools had sent out a total of 176,000-strong graduates, or an average of ca. 7,000 per institution. The oldest, First Higher School, alone accounted for 20,021 of those. In contrast, their little brothers managed to raise only about 24,000 among all of them during their existence of less than three decades (Hata, 2003, pp. 38-40).

\section{The Pedagogy of the Seven-Year Higher Schools: A Closer Look}

Why, then, bother at all to remember the few, short-lived institutions from a long ago? The answer is because "the empathic understanding of the whole past must become a power for shaping the future" (Dilthey, 1898). The significance of what these forgotten schools stood for, and how they raised their young charges, should be properly understood in relation to the present for the sake of the future.

\subsection{The Ideals to Pursue}

The historical records and the testimonials of the alumni of the 7-year schools reveal, with striking uniformity, the shared beliefs and ideals of their founders and professors, clearly conveyed by them to those under their tutelage. To begin with, the works of Rousseau, Pestalozzi, Fröbel, Demolins, Dewey, Steiner, Montessori, Ferrière, Neill and the like, were well known to many Japanese leaders in the 1920 s, a period that marked the peak years of the New Education Movement in that country (Kobayashi, 1967). Thus, many calls had been heard for much more diversified instructional styles than those centered around the recitation-and-memory tradition, so as to allow a self-involved, experiential learning and the cultivation of humane qualities in students at all levels. The innovators of the new institutions, some with direct personal experiences in Western cultures, were fully cognizant of that 
critical need. The shared aspiration was expressed by many different pioneers—humanists all—holding progressive views of education.

Not surprisingly, individualization, or the freedom to be one's own person, was uniformly emphasized in the new higher schools. Yet, it was not to be the mere self-centered individualism at the cost of the common good and group solidarity (Hendry, 1992). Each should strive to develop his unique endowment and personal qualities to the full for a larger, shared aim and the welfare of all. While the youth were admonished to look deeply into themselves, they were simultaneously encouraged to behold the whole wide world, well beyond the island boundaries of their own country. Thus, a proper balancing of the nurturance of strong moral character and the cultivation of deep knowledge was judged indispensable "just as the two wings of a bird" for "the triple ideals of the development of independent thinking, creation of a worldwide perspective, and integration of the best of the Eastern and Western cultural heritages" (Musashi, 1941, p. iii, p. 3).

Daily conveyed explicitly by their guides, these expectations could not fail making a deep impression on the young minds. The ideal was to become a person of enlightened mind with a broad perspective, sound body, solid moral character, rich emotional life, elegant decorum, and dedication to service to the common good. The gist of that message stayed with the chosen youngsters in forming the new "elite pluralism" of Japan (Nolte, 1984). In fact, it is striking to find, decades later, the identical refrains in the reminiscences of the alumni of differing 7-year schools. A common shorthand of that ethos was the image of the "gentlemanliness" in the best tradition of British public schools such as Eaton, Harrow, and Rugby (Hiramatsu et al., 1982).

As regards the intended contrasts in the demeanors of the students of the new vs. old higher schools, an amusing episode was recorded of an initial encounter at the Imperial University of Tokyo between a graduate of the Eighth High School (a 3-year institution in Nagoya) and "a group of strange type of fellow students". It turned out that these bizarre classmates of his, clearly distinguishable "in the way they talked and even in the manner they wore the school uniform", all happened to come from the 7-year schools (Hata, 2003, p. 88)!

It must be acknowledged, meanwhile, that, from the very beginning of the new higher schools, some concerns were expressed for the contrasts between certain features of their students and those in the older, 3-year institutions. Given the fact of their mostly metropolitan, middle-class family backgrounds, the younger ones tended to be perceived, justifiably or not, as "precocious and smart, but overprotected and light-weight", or "refined yet self-conscious, lacking in the robust, audacious qualities" (Hata, 2003, pp. 89-90; Tōkō A.A., 2001, p. 55, pp. 125-127). Allegedly, the missing features had been better embodied by the students in the 3 -year schools.

On the other hand, the slightly diffident, sensitive inclinations of the mostly city-grown, cosmopolitan students of the younger schools were freely acknowledged by many alumni themselves as both a welcome virtue, countering the often blatant egocentricity, hubris, and competitiveness of the old, and 
as a potential inhibitor of bold initiatives in thoughts and actions in the new (Furitsu A.A., 2005, pp. 125-127; Nagasaka, 1982, p. 226; Tōkō A.A., 2001, pp. 126-127).

\subsection{The Parents in the Wings}

Another important factor in the young world of the 7-year school students was the strong presence of solidly supportive parents, themselves representing "the new, largely urban professional and managerial elite in modern business enterprises, government, and social services" (Nolte, 1984, p. 667). Given the fact that all nine schools were located in or near the largest cities of Japan, the typical parents were those who had grown up in "the age of the middle class", which recorded, between 1909 and 1925 , an increase of more than 82 percent in mid-level business management and a 43 percent growth in the number of independent professionals (Shimabura, 1980). "That expansion of the overall size of the middle class went hand in hand with the working women becoming increasingly conspicuous within the ranks of white-collar employees. By the early 1920s, a wide range of occupations were open to women who possessed a high school or college diploma... [In fact], by 1922 approximately 3.5 million of Japan's 27 million women worked outside the home, slightly more than one-quarter of them in middle-class occupations. Moreover, the trend lines arched upward. Thus, for instance, there were 57,000 female nurses by 1926, in contrast to just 13,000 in 1911, and the number of female white-collar workers in government offices doubled between 1926 and the end of the decade" (McLain, 2007). In other words, most parents of the 7-year higher school students were themselves well-educated and upward-mobile white-collar workers. For instance, a 1936 survey of the parents of Naniwa students in the ordinary division showed 23.4 percent in large private enterprises, 22 percent of independent occupations, 11 in medicine, 7 in education, 3 each in real estate and government, 2 each in the ministry, mining, and arts, and the remaining 24.6 in other varied occupations (Hiramatsu, 1982, p. 18). Having lived with the new developments of the "geographic mobility, career competition, and the transition from extended to nuclear family - as well as the study of Western languages and textbooks predisposed this new elite to examine the implications of individualism" (Nolte, 1984, p. 667). Given that Zeitgeist, in which the concepts of individuality came to be widely broached in and out of the context of the collectivity, it is readily understandable that the professed ideals of the new higher schools-autonomy, character, and cosmopolitanism-attracted the attention of those parents. Of course, the financial burden carried by the parents for their child-schooling option was sizeable. For instance, the tuitions for the 1936 academic year at Naniwa (prefectual), was $¥ 75$ for the ordinary division students, and $¥ 95$ for the higher division ones. In addition, the school uniforms and other required learning necessities called for an additional outlay of about $¥ 65$. Meanwhile, at Seijō (private), the tuition for either division was reported as $¥ 200$ in 1937 (Kawatake, 1982, p. 144).

The official figures for the average monthly household income [the median range] of the whole nation were $¥ 70.27$ in 1936 and $¥ 69.93$ in 1937 (Japan Statistics Bureau, 2008, Table 20-2-a). Further, in 1938, only 4.1 percent of the families had "an annual income in excess of $¥ 1,200$ so as to be assessed the personal income tax" (Minami, 2008). Thus, philosophically and financially, the choice of the unique 
institutions in the 1930s was clearly a considered one on the part of the parents, reflecting their commitment to what these schools had uniquely to offer.

\subsection{The Competent Guides}

The professors of higher schools, old and new, were real "scholar-teachers"-all university-educated, and many of them with further study abroad. Quite a few among them were well-known authorities in their respective disciplines, and the typical roster also included some from foreign lands, especially in the language/literature area of study (Note 4).

Now, in the 7-year schools, true to the fundamental principle of pedagogical continuity and consistency, the same professors taught across all seven grades (Musashi, 2003, p. 27). The enthusiastic sharing of their vast knowledge and experience, in an iconoclastic style of each, explosively opened the perspective of the young learners to the life of the mind. The fully-equipped libraries also added support to the pursuits of the new explorers (Furitsu A.A., 1999, p. ii, 2005, pp. 124-25, pp. 129-130; Musashi, 2003, p. 27; Okazaki, 1999; Tōkō A.A., 2001, p. 111; Toyama, 2002, Vol. 1, p. 180). Not surprisingly, those encounters were not a simple routine for the young learners. For instance, they were faced with original, scholarly treatises to tackle, in lieu of the typical textbooks, and additionally urged to read as many works as possible of an erudite author of their choice. Many alumni acknowledged in their reminiscences the difficulty of that academic challenge, especially at the outset, which demanded considerable initiative and resilience on their part, individually and collectively. The mutual support and friendly competition were the often mentioned means of coping. "But, it became progressively easier, noted many an alumnus" (Furitsu A.A., 2005, p. 38, p. 44, pp. 124-127; Musashi, 2003, pp. 4-6; Tōkō A.A., 2001, pp. 201-212, p. 295).

\subsection{The Matter of Structure}

Now, the national average advancement rates (boys and girls together) onto the lower-secondary school level were 47 percent in 1918, 53 in 1926, and 60 in 1934 (Shammi, 1992). Nevertheless, within the multi-track schooling structure-in existence until 1947-the gate for those [boys] aiming at higher schools was much narrower. In fact, the admission rate into the preferred lower-secondary schools was approximately 10 percent from the 1920s on (Fugimura \& Terasaki, 2003, Table 1-1). The available figures for entry into the ordinary division of the 7-year higher schools reveal an equally selective pattern. Thus, in its opening year of 1922, Musashi attracted 1,102 applicants for the 80 seats, the rate being ca. 7 percent. Tōkō recorded 12 percent in 1922, and 13 in 1929. Meanwhile, in 1937, the rate at Furitsu was 11 percent, but it even dipped to a mere 5 percent in 1939. In the same year, Naniwa admitted only 7 percent of the applicants (Hata, 2003, p. 89; Musashi, 2003, p. 7; Nagasaka, 1982, p. 230; Tōkō A.A., 2001, p. 19, p. 24; Furitsu A.A., 1999, p. 21).

Meanwhile, as mentioned earlier, the success rates in the entrance examinations for 3-year higher school aspirants, following their 5-year lower-secondary school study, ranged mostly from 10 to 15 percent. In contrast, the boys in the 7-year schools advanced, after four years in the ordinary division, into the upper division in the same school, without any additional screening. Certainly, the absence of 
the extra filter was a blessing for those students, even though they would then have to face the ultimate hurdle into a chosen university at a younger age than those in the 3 -year track.

As to be elaborated later, what the particular structure of all these schools provided was, most critically, the pedagogical continuity and consistency through the sensitive stages of the middle childhood to adolescence.

\subsection{The Cross-Age Interactions in a Family-Like Environment}

Given their relatively small sizes, the schools created a supportive, family-like atmosphere, giving rise to a secure environment for sustained explorations of self, deep intellectual engagements, and individualized pursuits of interests, be they academic, artistic, athletic, spiritual, or social (Furitsu A.A., 2005, pp. 128-129; Sakano, 1982, pp. 74-75; Seikei, 1973, p. 400, p. 413, p. 418; Tōkō A.A., 2001, p. 127).

Besides, over and beyond the realms of academics, the young ones (so-called kōhai, or successors) were supported and guided by their senpai (predecessors) of the higher division who embodied the what-and-how of the experience of growing up. The four years of dense, continuous contacts throughout the campus in a big family atmosphere allowed the younger students to observe, listen, interact, learn, and emulate the older ones in all aspects of life.

In the face of the formidable odds, the kōhai looked up to the palpable competence and sophistication of the senpai and, convincing themselves, in the manner of The Little Engine That Could (Piper, 1930), that they too can climb the mountain. And, indeed, they did!

Being thus immersed in all the rich experiences in and out of the classrooms, the young learners in these schools also began wrestling early on with the crucial task of defining their respective, unique self. The pursuit was induced early by the nurturing presence of many older models, professors and senpai alike. Given one's own dreams, hopes, and fast-expanding perspectives, each student considered his aims in life, and pondered his long-range plans as a responsible citizen of the human community, small and large, near and far (Kusukawa, 1997; Teng-hui, 2003).

\subsection{Moving Up and Ahead}

After three years in the higher division, the students faced the dread entrance examination into a university of choice, hoping to succeed in the first, and only, attempt. Though the available records are scanty, the graduates fared well in passing the narrow gate to cross into higher education. Using the admission rates at the Imperial University of Tokyo as a measure for comparison (Tokyo Daigaku, 1987, pp. 474-478), one notes that the national average for the years, 1937-1941, was 55.3 percent into its Faculties of Law, Literature, and Economics. The top rates for the applicants from the Humanities Divisions of 3-year higher schools were 79.8 (Urawa), 72.9 (Shizuoka), and First (71.0). Meanwhile, the 7-year school graduates were recording 85.2 (Tōkō), 73.2 (Furitsu), and 72.8 (Musashi).

Similarly, the Faculties of Engineering, Sciences, Medicine, and Agriculture of said institution recorded the national admission rate of 55.8 percent for the same period. The top rates among the 
Sciences Division graduates from 3-year schools were attained by Urawa (72.3) and Shizuoka (63.1), while the 7-year counterparts registered 83.4 (Tōkō), 73.4 (Musashi), and 66.1 (Furitsu) (Note 5).

Though precise descriptions of the post-university pursuits of the 7-year higher school graduates are difficult at this late date, some relevant observations may still be made. For example, it is noted that many alumni of Tōkō, who had majored in jurisprudence, opted to pursue their career in the governmental agencies at the national and prefectural levels, as well as in banking industries, rather than in the body politic or independent practice. Meanwhile, for an epoch, four successive ambassadorial seats in the United Kingdom were occupied by the graduates of that single school. Meanwhile, many of its equally large science/engineering cohort headed into the private industries of aeronautics, high-speed trains, automobiles, atomic energy, and optics, to name a few. Another notable record there is that close to 17 percent of the total alumnus group occupied professorial chairs in all fields at numerous national, prefectural, private, and foreign universities (Tōkō A.A., 2001, pp. 154-172).

A similar trend was detected at Furitsu. Its alumni were fewer in the body politic, private legal practice, or journalism, than in large enterprises of all sorts-finance, insurance, international trades, engineering, manufacturing, transportation, communications, energy, etc., and also in numerous governmental ministries. There, again, at one time, its graduates simultaneously held the ambassadorships to five different countries. Roughly 7 percent of all the alumni were found in medical practice, and 9 percent held the professorial chairs in higher education (Nagasaka, 1982, pp. 231-234). A report on the graduates of Naniwa also reflected a generally similar picture. In 1979, 47 percent of its 3003 living alumni were working in private enterprises, while 13 percent were university professors (Hiramatsu, 1982, p. 30).

Thus, it may be safely stated that, in the face of the extraordinarily disruptive historical events involving them, and in spite of their very short lifespan,, these few schools of yore were fulfilling their mission, raising their share of learned citizens of character, vision, competence, and drive in diverse endeavors - those sorely needed in the tumultuous decades of the collapse and resurgence of the whole nation.

\section{The Latter-Day Vindication}

Interestingly, quite a few recent studies-East and West - provide the confirmation of the pedagogical significance of many an element in the bygone efforts of these few institutions.

\subsection{Parental Support and Guidance}

It was observed earlier that the choice of the alternate, 7-year route was a considered one on the part of the respective parents, requiring much involvement—financially and otherwise —on their part. Some confirming findings have been reported more recently on the critical parental functions in relation to the youngsters under their care. For instance, the household educational expenditures in Japan for the year 2008 was recorded to represent about 7-8 percent of the average disposable [annual] family 
income of $¥ 6,100,000$ for a child in the pubic lower-secondary school, and 8-9 percent in the upper-secondary school (MEXT, 2009, Figure 1-1-2). In the case of the private institutions, the cost was at least twice. Hence, obviously, the financial burden on the parents remains sizeable.

As regards certain other aspects of the family interactions, two large surveys of close to 2,400 lower-secondary and 4,500 upper-secondary Japanese students, all in their second year, showed 68 percent at each level to have frequent conversations with their parents, including calls for assistance on school work. Frequent parental exhortations on hard studying was reported by 20-30 percent of these learners, while the expression of parental desire for a good tertiary education experience was acknowledged by 20-40 percent of the offspring (Benesse, 2006, p. 21).

Another study, including 800 lower-secondary and 1,200 upper-secondary school students, reported that 44 percent of the former and 38 percent of the latter reported having conversation with their parents "very often", while 35 percent and 43 percent, respectively, "often". In terms of the reception of parental praises and encouragements, the noted proportions were 18 and 14 for "very often", and 40 and 42, "often". As for the parental exhortation on dirigent studying, the figures were 21 and 19 for "very much", and 35 and 40 for "much" (Nihon Seishōnen Kenkyūjo, 2009, p. 7). Thus, the presence of considerable parental involvement in the schooling of the young, accompanied by strong, overt expectations about the latter's scholastic future, appears to have remained a notable factor in the child's present and future. At least one study at the lower-secondary school level showed a significant correlation between the extent of parent-child contact and the child's academic performance (Benesse, 2001, p. 2, p. 5, p. 9). Meanwhile, within the United States itself, a study by Rand Corporation concluded that "close connections and communication between parents and young teens are associated with better school performance and psychosocial adjustment" (Juvonen et al., 2004, p. 86).

\subsection{The Structural Articulation}

The benefit of the educational continuity in the integral school structure has also been confirmed by recent U.S. studies, triggered by the disappointing performance of the middle-grade schools. Now, back "in 1920, 94 percent of [U.S.] secondary schools still followed the traditional pattern of four years [of high school] on top of eight years of elementary school..." (Tyack \& Cuban, 1995, p. 71). Then, the very high attrition rates observed led the reformers to argue for "only six elementary grades... and a new kind of school, the junior high school... in place of grades seven and eight or nine... [so as] to tailor the work of school to the particular stage of development of young teenagers" (ibid., p. 70). The same rationale was invoked again for the establishment in the 1980s of the middle school, typically inserted in grades 6 through 8 , to "make the old junior high school more developmentally responsive" (Juvonen et al., 2004, p. 112). However, further research came to the conclusion that most American junior high and middle schools do not meet the developmental needs of their students. On the contrary, "they are an arena of casualties, among both students and teachers" (Hamburg, 1989, p. 5). Other researchers agreed on the interpretation of the causal difficulties (e.g., Ianni, 1989; Entwisle, 1990; Hamburg, 1992). More recently, a Rand Corporation study categorically characterized "the transition 
as culprit". In a nutshell, "students do best in educational settings that provide social support and emphasize academic rigor". But, "multiple simultaneous changes (for example, the onset of puberty and school transfer) are stressful and sometimes have long-lasting negative effects" (Juvonen et al., 2004, p. 18).

The said report thus closed with the following statement, corroborating the basic advantages of the 7 -year higher schools of eight decades ago across the sea. "We need to keep in mind that, from developmental, organizational, and educational perspectives, continuity rather than change is likely to provide better conditions for student growth, institutional improvement, and educational progress. Thrashing about from educational fad to educational fad is not likely to pay high dividends" (ibid., p. 119).

As a matter of fact, already back in 1971, the Japanese Central Council for Education was raising the idea of "new strategies for linking lower and upper secondary schools" in its report to the Ministry of Education (MEXT, 1980, Appendix 1). Close to two decades later, on the occasion of the March 1989 revision of the Courses of Study, the National Council on Educational Reform [formed in September 1984] included on its list of implemented [sic] measures "the institutionalization of six-year unified lower and upper secondary education schools" (MEXT, 2001, Introduction: Section 4-1-3).

However, in 1999, the Central Council for Education was again calling attention of the Ministry of Education to the issues of student transition in its December 16 report, "Regarding Reform of Continuity between Primary and Lower- and Upper-Secondary Schools, and Universities" (Chūō Kyōiku Shingikai, 1999). Subsequently, in its 2000 White Paper, the Ministry acknowledged the presence of only 17 "unified lower-and-upper-secondary schools" in the whole nation, yet described them as an institution wherein "each and every student is able to learn in a relaxed atmosphere amid a coherent educational content and environment lasting six years from lower to upper secondary school" (MEXT, 2000, Section 2, Question 8). Alas, the figure of 17 represented 0.15 percent of the nation's 11,209 lower-secondary schools and 0.3 percent of the 5,478 upper-secondary schools (ibid., Chousa01/kihon/kekka). Meanwhile, "the emerging tier of elite private high schools that offer six-year secondary programs" came to be known for their good record for successfully sending their graduates to select universities (Kelly, 2002, p. 248; Tōkō A.A., 2001, p. 130, p. 132). Ten years later, in 2010, the number of the articulated high schools in the nation increased to 402; yet, it was still only 3.7 percent of total, 10,815 lower-secondary schools and 7.9 percent of 5,116 upper-secondary schools. Besides, 221 (= 55 percent) of those 402 unified schools were private institutions (MEXT, 2001, p. 12; Japan Statistics Bureau, 2011, Table 16.1).

The past aside, the interest in the linked school structure is apparently running high at this juncture, and the trend for unification appears to have received further impetus from a recent announcement by the special committee of the Metropolitan Tokyo, deliberating on the fundamental notion of school articulation. In its August 2013 report, the committee proposed a plan to open, by 2017, a single institution unified over the whole 12-year span of primary-lower secondary-upper secondary schools Published by SCHOLINK INC. 
(Metropolitan Tokyo Study Committee, 2013). Since the Metropolitan Tokyo already hosts, in its private school sector, 168 of the articulated structure among the 233 upper-secondary plus 185 lower-secondary schools (Tokyoto, 2013, Chapter 1, Table 1), the projected move for a pioneering prefectural institution is certain to receive much interest and close scrutiny from all Japan.

\subsection{The Dynamics of Mutual Nurturing}

As noted earlier, in addition to avoiding the negative effects of change (i.e., the untimely transitions), the unified structure of the 7-year higher schools allowed the spontaneous cross-age interactions among the students on a daily basis. Indeed, the natural modeling by the older students (senpai) was a salient component of the educative process for the younger ones (köhai) in all realms of school life. Not surprisingly, the individual soul-searching was an integral part of that experience. In relation to the contemplative pursuit, the findings of an American longitudinal study (Clausen, 1995) are instructive. The research followed the life of nearly 300 men and women, all "children of the Great Depression", over a span of six decades. The results revealed that "an adolescent's competence by the end of their high school years - planful competence-influences the scheduling of the major social roles later occupied, the stability of role performance, and the person's attainment and life satisfaction over much of the life course (p. 18). Also to be remembered is that, like in the good one-room American schools of yore (Leight \& Rinehart, 1992, pp. 133-151), the environment of a "society in miniature" allowed the middle-childhood learners of the 7-year schools ample opportunities to observe, listen, interact, study, and emulate. Thus, they could and did "review and preview" their school lessons as well as their own lives. The constructive effects of that kind of arrangement were further recognized in an extensive review of American studies on multi-grade instruction: "social competence develops for older children out of their roles as teachers and nurturers, and for younger children out of their opportunity to observe and model the behavior of their older classmates" (Northwest Regional Educational Laboratory, 1999, pp. ix-x).

In that vein, the consistency over time in relationships among teachers, children, and parents is viewed as one of the most significant strengths of the multi-grade approach, because it encourages greater depth in children's social, academic, and intellectual development. The concept of the classroom as a "family" is encouraged there, leading to expansion of the roles of nurturing and commitment on the part of both the students and teachers (ibid., p. ix). Meanwhile, it goes without saying that the role teachers play is critical in the whole dynamics of the creation of a learning space, relatively free of the effects of the typically graded nature of the schooling and its mainly lock-step, content-anchored curriculum (Eckert, Goldman, \& Wenger, on-line). Even in the mass-access schooling in a globalized, information society, wherein "virtuality becomes an essential dimension of... reality" (Castells, 2010, p. xviii), it remains essential to recognize that some kinds of education, perhaps the most important kinds, involve the shaping of mind and character, not only the way we think but also the way we feel and see the world. That kind of education... requires that people care about one another beyond their usefulness to one another as carriers or recipients of bodies of information and skill... Moreover, some of the most 
important kinds of knowledge are "tacit", not fully articulated or rationalized, gained through apprenticeship and direct association with those who possess it" (Trow, 2007, p. 277).

It may be posited that all the support and guidance accorded the students of the 7-year schools reflected a tacit acknowledgment of their character and competence. In return for that trust, the young arrived at the spontaneous formation of their own "community of collaborative learners" (Bruner, 1966, p. 39). In time, their growing "agentive efficacy" and "self-esteem" transformed the whole experience into "a pedagogy of mutuality" (ibid., p. 39, p. 56).

\subsection{Acknowledgement of the Proud Tradition}

In 1964, Japan joined the Organization for Economic Co-operation and Development (OECD) as its first non-European member and, starting in 2000, has also taken part in its triennial Program for International Student Assessment (PISA), an achievement testing of sample 15 year-olds in reading, mathematics, and science. Further, beginning in 1995, Japan has also participated in the quadrennial achievement testing program of sample $4^{\text {th }}$ and $8^{\text {th }}$ graders by the International Association for the Evaluation of Educational Achievement, called The Trends in International Mathematics and Science Study (TIMSS).

While certain limitations, technical or interpretive, have been acknowledged (e.g., Prais, 2003; Jerrim, 2011), these test results have been useful as a rough index of the status of the educational efforts of the respective nations. In addition, the OECD has been publishing, from time to time, its own, comprehensive report on, and thoughtful assessments of, the; pedagogical efforts of the select members. The series is called Strong Performers and Successful Reformers in Education, and its 2010 report contained a chapter bearing the title, "Japan: A Story of Sustained Excellence". Its conclusion read: while there may be specific features of the Japanese system [of education] that are unpalatable, it is a system which bears careful scrutiny. It has contributed to a country with very high levels of school and academic achievement. Its students enjoy school more than most... Parents in Japan participate in their children's education and partner with teachers to an unusual degree. The country has one of the world's most admired curriculums. Though the system continues to evolve, the methods used to build this system should surely be considered by any country that wants to match its achievements (OECD, 2010, p. 152).

In its even more detailed analyses and recommendations two years later, titled Lessons from PISA for Japan, the world body offered the following observations.

[Japan has] a culture in which great value is placed on education and skills on the one hand, and on the group and social relations on the other... Japan has built one of the best educated, most flexible, fastest learning and uniformly high-calibre workforces in the world. The nation is brilliant at continuously improving products and processes... Who is to say which is more important, the occasional breakthrough or continuous improvement? ... Japan's commitment to children has not just been rhetorical, but a concrete and enduring priority, for which students, parents, and educators and the nation as a whole were prepared to make real sacrifices. This commitment is the foundation of the 
Japanese system. It is the main reason why Japan has access to a first-rate teaching force, Japanese students are superbly supported at home, and schools are well resourced... Many lessons drawn from Japan's experience with education are useful for analytical purposes, but risk obscuring a very important aspect of the Japanese educational system. The system is designed not only to develop students' cognitive capacities, but also to inculcate the society's values of ethical behavior, meritocratic advancement and social cohesion in those students... (OECD, 2012, p. 180, p. 186, p. 187, p. 191, p. 192).

\section{Harking Back}

Thus, looking back almost a century, one realizes that a handful of 7-year higher schools truly aimed high — through their articulated structure and progressive pedagogy — to cultivate in their charges a sound body, lofty spirit, autonomy of thought, breadth of perspective, depth of scholarship, richness of affect, and rectitude of morals. Given the short lifespan of barely three decades, it would be unrealistic to expect a full realization of the exalted ideal. Yet, the mere fact of their existence and their innovative efforts during one of the most turbulent decades in the life of the nation make their reforming venture a highly significant one, offering much to inform the here-and-now and beyond. Indeed, the nine special institutions of Imperial Japan represented a meaningful educational venture, not to be simply written off and forgotten.

\section{References}

Benesse Educational Research and Development Center. (2001). "Oya-to Yoku Hanashi-o Shite-iru Ko-no Tokuchō" (The characteristics of children who talk often with their parents). The Third Survey on School Learning. Tokyo: Author.

Benesse Educational Research and Development Center. (2006). "Katei Kankyō-to Gakushū" (The home environment and school learning). The Fourth Survey on School Learning. Tokyo: Author.

Bowring, R., \& Kornicki, P. (Eds.). (1993). The Cambridge Encyclopedia of Japan. Cambridge, U.K.: Cambridge University Press.

Bruner, J. (1996). The Culture of Education. Cambridge, MA: Harvard University Press.

Castells, M. (2010). The Rise of the Network Society (2nd ed.). Chichester, U.K.: Wiley-Blackwell.

Chuō Kyōiku Shingikai (Central Education Council). (1999). Shotō/Chūtō-Kyōiku to Kōtō-Kyōiku to-no Setsuzoku no Kaizen ni tsuite (Report on the Improvement of the Coordination betweem the Primary/Lower-Secondary Education and the Upper-Secondary Education). Tokyo: Nihon Monbu Kagaku Shō (MEXT).

Clausen, J. A. (1995). American Lives: Looking Back at the Children of the Great Depression. Berkeley, CA: University of California Press.

Daniels, R. (1977). The Politics of Prejudice: The Anti-Japanese Movement in California and the Struggle for Japanese Exclusion. Berkeley, CA: University of California Press. 
Dilthey, W. (1898). Present-day Culture and Philosophy. In H. P. Rickman (Ed.), W. Dilthey: Selected Writings (pp. 109-121). Cambridge, U.K.: Cambridge University Press.

Divine, R. A. (1965). The Reluctant Belligerent: American Entry into World War II. New York: John Wiley and Sons.

Dower, J. W. (1999). Embracing Defeat: Japan in the Wake of World War II. New York: W. W. Norton.

Duke, B. C. (1989). Variations on Democratic Education: Divergent Patterns in Japan and the United States. In J. J. Shields, Jr. (Ed.), Japanese Schooling: Patterns of Socialization, Equality, and Political Control (pp. 260-269). University Park, PA: The Pennsylvania State University Press.

Eckert, P., Goldman, S., \& Wagner, E. (n.d.). The School as a Community of Engaged Learners. Palo Alto, CA: Institute for Research and Learning. Retrieved from http://www.stanford.edu/ eckert/PDF/SasCEL.pdf

Entwisle, D. R. (1990). Schools and the Adolescent. In S. S. Feldman, \& G. R. Elliott (Eds.), At the Threshold: The Developing Adolescent (pp. 197-224). Cambridge, MA: Harvard University Press.

Fugimura, M., \& Terasaki, S. (2003). Chihō-ni-okeru Kyūsei Kotō Kyōiku Kikan Riyōsō-no Hikaku Bunseki: Nīgata Kōtō Gakkō-to Nīgata Ika Daigaku-o Jireini (A comparative analysis of the social origins, educational careers, and destinations of students in Nīgata High School and Nīgata Medical College: 1919-1948). Hiroshima: Hiroshima Daigaku, Kōtō Kyōiku Kenkyū Kaihatsu Sentã (Higher Education Research Development Center, Hiroshima University).

Furitsu Kōtō Gakkō Dōsōkai. (1999). Yakumo: Furitsu Kōtō Gakkō Sōritsu Nanajūnen Kinengō (Yakumo: Furitsu Higher School $70^{\text {th }}$ anniversary issue). Tokyo: Author [Furitsu Alumni Association].

Gadamar, H.-G. (1986). Truth and Method. New York: Crossroad.

Gluck, C. (1993). Foreword. In G. H. Tsuchimochi (Ed.), Education Reform in Postwar Japan: The 1946 U.S. Education Mission (pp. ix-xvi). Tokyo: University of Tokyo Press.

Hamburg, D. A. (1989). Early Adolescence: A Critical Time for Interventions in Education and Health. New York: Carnegie Corporation of New York.

Hamburg, D. A. (1992). Today's Children: Creating a Future for a Generation in Crisis. New York: Times Books.

Hanley, S. B. (1997). Everyday Things in Premodern Japan. Berkeley, CA: University of California Press.

Harootunian, H. D. (1993). America’s Japan/Japan’s Japan. In M. Miyoshi, \& H. D. Hartoonian (Eds.), Japan in the World (pp. 196-221). Durham, NC: Duke University Press.

Hata, I. (2003). Kyūsei Kōkō Monogatari (The story of the old-system higher schools). Tokyo: Bungei Shunjū.

Hendry, J. (1992). Individualism and Individuality. In R. Goodman, \& K. Refsing (Eds.), Ideology and Practice in Modern Japan (pp. 55-71). London: Routledge. 
Hiramatsu, S., Fukai, T., \& Sasa, K. et al. (1982). Kyūsei Hichinensei Kōkō (The old-system, 7-year higher schools). Tokyo: Gakugei Shorin.

Ianni, F. A. J. (1989). The Search for Structure: A Report on American Youth Today. New York: The Free Press.

Jansen, M. B. (2000). The Making of Modern Japan. Cambridge, MA: Belknap Press, Harvard University.

Japan Ministry of Education, Culture, Sports, Science, and Technology—See entries under MEXT below.

Japan Statistics Bureau, Ministry of Internal Affairs and Communications, Tokyo (2008). Historical Statistics of Japan (Table 20-2-a).

Japan Statistics Bureau, Ministry of Internal Affairs and Communications, Tokyo (2011). Statistical Handbook of Japan (Table 16-1).

Japan Statistics Bureau, Ministry of Internal Affairs and Communications, Tokyo (2013). Statistical Handbook of Japan 2013 (Table 2-2).

Jerrim, J. (2011). England's “Plummeting” PISA Test Scores between 2000 and 2009: Is the Performance of Our Secondary School Pupils Really in Relative Decline (DoQQS Working Paper No.11-09)? London: Department of Quantitative Social Science, Institute of Education, University of London.

Juvonen, J., Kaganoff, V.-N. Le, Augustie, T. C., \& Constant, L. (2004). Focus on the Wonder Years: Challenges Facing the American Middle School. Santa Monica, CA: Rand Corporation.

Kawatake, T. (1982). Kyūsei Seijō Kōtō Gakkō (Old-system Seijō Higher School). In S. Hiramatsu et al. (Eds.), Kyūsei Hichinensei Kōkō (Old-system 7-year higher schools) (pp. 139-170). Tokyo: Gakugei Shorin.

Kelly, W. W. (2002). "At the Limits of New Middle Class Japan: Beyond 'Mainstream Consciousness"'. In O. Zunz, L. Schoppa, \& N. Hiwatari (Eds.), Social Contract under Stress: The Middle Classes of America, Europe and Japan at the Turn of the Century (pp. 232-254). New York: W. W. Norton.

Kobayashi, V. (1967). Progressive Education and the National Development in Japan. Teachers College Record, 68(6), 551-557.

Kōdansha. (1993). Japan: An Illustrated Encyclopedia. Tokyo: Author.

Kōnan Gakuen. (1969). Kōnan Gakuen-no Gojūnen (The 50 years of Kōnan schools). Kobe, Japan: Author.

Kusukawa, J. (1997). Ritsushi (Firm resolution on the aim of one's life). Kinenkan Dayori [Newsletter of the Old-system Higher School Memorial Hall (Matsumoto, Japan)], 11, 1-3.

Lee, T.-H. (2003). Bushidō Kai-dai (Notes on \{Nitobe's\} Bushidō). Tokyo: Shōgakukan.

Leight, R. L., \& Rinehart, A. D. (1992). Revisiting Americana: One-Room School in Retrospect. The Educational Forum, 56(2), 133-151. 
McClain, J. L. (2007). "The Age of the Middle Class" (A public lecture in August 2007). Retrieved from http://www.aboutjapan.japansociety.org/page/japaneducation_home

MEXT [All titles were written and published by the Ministry of Education, etc., in Tokyo]. (1980). Japan's Modern Educational System.

MEXT [All titles were written and published by the Ministry of Education, etc., in Tokyo]. (2000). Toward a Culturally-Oriented Nation.

MEXT [All titles were written and published by the Ministry of Education, etc., in Tokyo]. (2001). Educational Reform for the $21^{\text {st }}$ Century.

MEXT [All titles were written and published by the Ministry of Education, etc., in Tokyo]. (2009). Educational Standards and Educational Expenditure in Japan.

MEXT [All titles were written and published by the Ministry of Education, etc., in Tokyo]. (2009). Trends and Development in Education, Science, and Technology Policies.

Minami, R. (2008). Income Distribution of Japan: Historical Perspective and Its Implications. Japan Labor Review, 5(4), 15.

Musashi Kōtō Gakkō (Musashi Higher School). (1941). Musashi Kōtō Gakkō Nijūnenshi (The 20-year history of Musashi Higher School). Tokyo: Author.

Nagasaka, S. (1982). Furitsu Kōtō Gakkō (Furitsu Higher School). In S. Hiramatsu et al. (Eds.), Kyūsei Hichinensei Kōkō (The old-system, seven-year higher schools) (pp. 219-245). Tokyo: Gakugei Shorin.

Natsume, S. (1957). Kokoro (The heart of things). (E. McClellan, Trans.). Chicago: Regnery Gateway.

Nezu Ikueikai (Nezu Talent Nurturance Society). (2003). Musashi Hachijūnen-no Ayumi (The 80-year Strides of Musashi). Tokyo: Author.

Nihon Seishōnen Kenkyūjo (Japan Youth Research Institute). (2009). Chūgakusei-to Kōkōsei-no Seikatsu-to Ishiki (The life and perceptions of lower- and upper-secondary school students). Tokyo: Author.

Nitobe, I. (1908). Bushidō: The Soul of Japan (The way of samurai warriors). (13th ed.). Retrieved from http://www.gutenberg.net/1/0/2/3/12096 (e Book \#12096.txt)

Nolte, S. H. (1984). Individualism in Taishō Japan. Journal of Asian Studies, 43(4), 667-684.

Northwest Regional Educational Laboratory. (1999). The Multigrade Classroom: A Resource Handbook for Small, Rural Schools. Portland, OR: Author.

Officer, L. H., \& Williamson, S. H. (2012). Five Ways to Compute the Relative Values of a Japanese Yen Amount. In Measuring Worth (pp. 1879-2011). Retrieved from http://www.measuringworth.com/japancompare/

Ohno, K. (2006). The Economic Development of Japan; The Path Traveled by Japan as a Developing Country. Tokyo: GRIPS Development Forum, National Graduate Institute for Policy Studies.

Okazaki, H. (1999). On the Future of Education in Japan. Daily Yomiuri. Retrieved from http://www.okazaki-inst.jp/elite.engdy112299.html 
Organization for Economic Co-operation and Development (OECD), Paris. (2010). Strong Performers and Successful Reformers in Education: Lessons from PISA for the United States.

Organization for Economic Co-operation and Development (OECD), Paris. (2012). Strong Performers and Successful Reformers in Education: Lessons from PISA for Japan.

Piper, W. (1930). The Little Engine That Could. New York: Platt and Munk.

Prais, S. J. (2003). Cautions on OECD's Recent Educational Survey (PISA). Oxford Review of Education, 29(2), 139-163.

Reynolds, E. B. (1994). Thailand and Japan's Southern Advance, 1940-1945. London: Macmillan.

Rose, B. (1992). Tsuda Umeko and Women's Education in Japan. New Haven, CT: Yale University Press.

Rubinger, R. (1989). Continuity and Change in Mid-Nineteenth-Century Japanese Education. In J. J. Shields, Jr. (Ed.), Japanese Schooling: Patterns of Socialization, Equality, and Political Control (pp. 224-233). University Park, PA: The Pennsylvania State University Press.

Sakano, K. (1982). Kyūsei Kōnan Kōtō Gakkō (Old-system Kōnan Higher School). In S. Hiramatsu, T. Fukai, \& K. Sasa et al. (Eds.), Kyūsei Hichinensei Kōkō (Old-system 7-year higher school) (pp. 53-75). Tokyo: Gakugei Shorin.

Sasaki, K. (2008). Between Emigration and Immigration: Japanese Emigrants to Brazil and Their Descendants in Japan. Senri Ethnological Reports, 77, 53-66.

Seijō Gakuen. (1998). Seijō Gakuen Hachijunen (The 80-year history of Seijō Schools]. Tokyo: Author.

Seikei Gakuen. (1973). Seikei Gakuen Rokujūnenshi (The 60-year history of Seikei Schools). Tokyo: Author.

Shammi, D. (1992). Entrance Examinations in Prewar Japan, Late Meiji to 1941 (p. 87, Table 1). Master's thesis, University of British Columbia.

Shimabura, M. (1980). Daitoshi-ni-okeru Kenryoku-to Minshū-no Dōkō (The big city trends in the relationship between the authority and the people). In H. Koyama (Ed.), Taishōki-no Kenryoku-to Minshu (The authority and the people in the Taishō period) (pp. 46-72). Kyoto: Hōritsu Bunkasha.

Tokyo Kōtō Gakkō Dōsōkai (Tokyo Higher School Alumni Association). (2001). Kyūsei Tokyo Kōtō Gakkō-Jentoruman Kyōiku-no Kiseki (Old-system Tokyo Higher School-The Locus of Gentlemanship Education). Tokyo: Author.

Tokyo Daigaku. (1987). Tokyo Daigaku Hyakunenshi (The centennial history of the University of Tokyo). Tokyo: Author.

Toritsu Shō-Chū-Kō Ikkan Kyōiku-kō-no Kosō Kentō linkai (Metropolitan Tokyo Study Committee to Consider the Notion of an Articulated Primary-Secondary-High School). (2013). Chükan Matome (Interim Report). Tokyo: Author.

Toyama, Daigaku. (2002). Toyama Daigaku Gojūnenshi (50-year history of Toyama University). (Vol. 2). Toyama, Japan: Author. 
Trow, M. A. (2007). Reflection on the Transition from Elite to Mass to Universal Access: Forms and Phases of Higher Education in Modern Societies since WWII. In J. J. F. Forest, \& P. G. Altbach (Eds.), International Handbook of Higher Education (Vol. 1, pp. 243-280). Dordrecht, Netherlands: Springer.

Tsuchimochi, G. H. (1993). Education Reform in Postwar Japan: The 1946 U.S. Education Mission. Tokyo: University of Tokyo Press.

Tyack, D., \& Cuban, L. (1995). Tinkering toward Utopia. Cambridge, MA: Harvard University Press. Yakumo: Furitsu Kōtō Gakkō Sōritsu Nanajūgonen Kinengō (Yakumo: Furitsu Higher School $75^{\text {th }}$ anniversary Issue). (2005). Tokyo: Author.

Yamamoto, T. (1999). Masking Selves, Making Subjects: Japanese American Women, Identity, and the Body. Berkeley, CA: University of California Press.

Yoshino, M., \& Kusano, A. (1999). Sawayanagi Masatarō-no Joshi Kōtō Kyōikukan: Tōhoku Teikoku Daigaku-ni-okeru Josei-ë -no Monko Kaihō-o Chūshin-ni-shitë (Masatarō Sawayanagi’s view on higher education of women-focusing on his door-opening to women at Tohoku Imperial University). Nihon Kasei Gakkaishi (Journal of Japan Home Science Association), 50(5), 433-442.

\section{Notes}

Note 1. "MEXT" is the shorthand for the Japanese Ministry of Education, Culture, Sports, Science, and Technology.

Note 2. The Taihoku Higher School, established in current Taipei in 1922, was under the jurisdiction of the Japanese Government General of Taiwan.

Note 3. Henceforth, only the proper names of the higher schools shall be given. To prevent confusion, Tokyo Higher School shall be called "Tōkō".

Note 4. "A.A." stands for "Alumni Association".

Note 5. English was taught for full 7 years, while another language was introduced in the "higher courses" of 3 years (mostly German, plus French).

Note 6. Of course, it should be noted that the advance rates of the graduates from either system of higher schools reached 97 percent and above when the figures from several other, highly-rated universities and specialized institutions were incorporated. 